\title{
FAKTOR YANG BERHUBUNGAN DENGAN PERILAKU MINUM OBAT DALAM PEMBERIAN OBAT PENCEGAHAN MASSAL FILARIASIS DI KABUPATEN BANYUASIN TAHUN 2015
}

\author{
Ritawati, ${ }^{1 *}$ Reni Oktarina ${ }^{2}$, Indah Margarethy $^{1}$ \\ ${ }^{1}$ Balai Penelitian dan Pengembangan Kesehatan Baturaja \\ JI. A.Yani KM.7 Kemelak Baturaja, 32111, Kabupaten Ogan Komering Ulu, Sumatera Selatan, Indonesia \\ ${ }^{2}$ Badan Penelitian dan Pengembangan Daerah \\ Provinsi Sumatera Selatan, JI. Demang Lebar Daun No. 4864, Palembang, 30137, Kota Palembang \\ Sumatera Selatan, Indonesia
}

\begin{abstract}
Lymphatic Filariasis (LF) is an infectious disease caused by Wuchereria bancrofti, Brugia malayi and Brugia timori, which causes lymph fluid to become blocked and swelling of the legs and arms. Elimination of lymphatic filariasiswas carried out through a program of providing mass preventive drugs to all residents in endemic areas once a year for five years. Banyuasin regency has seen a decrease in the prevalence rate of microfilariae, however the risk of transmission still occurs because new cases found after third period of mass drug administration (MDA) in sentinel site with high density of microfilaria in the blood sample. The success to eliminate LF requires high levels of compliance of MDA. This study aimed to determine the factors associated with the behavior of drug uptake in the mass drug administration. This type of quantitative analytic research with a cross-sectional design was carried out in 2015 in Banyuasin Regency. Interviews using a questionnaire were conducted to 302 respondents with systematic random sampling. Factors related to the behavior of drug uptake were the level of perception of drug side effects, public knowledge, drug distribution methods, and counseling. The dominant factor influencing the behavior of drug uptake is the counseling, so it is necessary to increase knowledge to the public by counseling that the drug side effects are body response to dying parasites.
\end{abstract}

Keywords: Filariasis, mass prevention of drugs administration, drugs side effects, behavior.

\section{FACTORS RELATED TO DRUG UPTAKE IN MASS DRUG ADMINISTRATION AGAINST FILARIASIS IN BANYUASIN REGENCY 2015}

\begin{abstract}
Abstrak
Filariasis adalah penyakit infeksi yang disebabkan oleh Wuchereria bancrofti, Brugia malayi, dan Brugia timori, yang menyebabkan cairan getah bening tersumbat dan bengkak pada kaki dan lengan. Eliminasi filariasis dilakukan melalui program pemberian obat pencegahan massal kepada seluruh penduduk di daerah endemis setahun sekali selama lima tahun. Kabupaten Banyuasin telah mengalami penurunan angka prevalensi mikrofilaria. Namun risiko penularan masih terjadi karena kasus baru ditemukan setelah periode ketiga pemberian obat massal (POPM) di lokasi sentinel dengan kepadatan mikrofilaria yang tinggi dalam sampel darah. Keberhasilan program eliminasi filariasis membutuhkan tingkat kepatuhan POPM yang tinggi. Penelitian ini bertujuan untuk mengetahui faktor-faktor yang berhubungan dengan perilaku minum obat dalam pemberian obat massal. Jenis penelitian ini adalah analitik kuantitatif dengan desain cross sectional ini dilaksanakan pada tahun 2015 di Kabupaten Banyuasin. Wawancara menggunakan kuesioner dilakukan kepada 302 responden dengan pengambilan sampel secara acak sistematis. Faktor-faktor yang berhubungan dengan perilaku penggunaan obat adalah tingkat persepsi efek samping obat, pengetahuan masyarakat, metode distribusi obat, dan penyuluhan. Faktor dominan yang mempengaruhi perilaku pengambilan obat adalah
\end{abstract}


penyuluhan, sehingga perlu dilakukan peningkatan pengetahuan kepada masyarakat dengan penyuluhan bahwa efek samping obat adalah respon tubuh terhadap kematian parasit.

Kata Kunci: Filariasis, pemberian obat pencegahan massal, efek samping obat, perilaku.

Naskah masuk: 01 Juli 2020; Review: 14 Juli 2020; Layak Terbit: 08 Desember 2020

*Alamat korespondensi penulis pertama: e-mail: ritabaturajabta@gmail.com; Telp: (0735) 325303

\section{PENDAHULUAN}

Filariasis adalah penyakit menular menahun yang disebabkan oleh cacing filaria Wuchereria bancrofti, Brugia balayi, dan Brugia timori yang menyerang saluran dan kelenjar getah bening. Penderita filariasis adalah seseorang yang dalam pemeriksaan darahnya mengandung mikrofilaria dan/atau dengan hasil pemeriksaan deteksi antigen positif dan/atau memiliki gejala klinis filariasis. Salah satu upaya eliminasi penyakit tersebut yaitu melakukan kegiatan Pemberian Obat Pencegahan massal (POPM). Kegiatan POPM filariasis adalah pemberian obat yang dilakukan untuk mematikan mikrofilaria secara serentak kepada semua penduduk sasaran di wilayah endemis filariasis. ${ }^{1}$

Indonesia telah melakukan program eliminasi filariasis sejak tahun 2002 dengan menerapkan program pengobatan massal. Pengobatan massal filariasis menggunakan kombinasi obat Diethycarbamazine Citrate (DEC) $6 \mathrm{mg} / \mathrm{kg}$ berat badan, Albendazole $400 \mathrm{mg}$ dan Paracetamol $500 \mathrm{mg}$ yang diberikan sekali setahun selama minimal 5 tahun berturut-turut. ${ }^{2}$

Provinsi Sumatera Selatan merupakan salah satu daerah endemis filariasis di Indonesia. Banyuasin merupakan kabupaten dengan jumlah penderita filariasis terbanyak di Sumatera Selatan. Program POPM filariasis untuk seluruh desa/kelurahan se-Kabupaten Banyuasin baru dilaksanakan pada tahun 2011. Cakupan penduduk yang harus minum obat adalah $85 \%$ dari sasaran penduduk. Cakupan POPM yang tinggi $(>85 \%)$ diharapkan dapat memutuskan mata rantai penularan filariasis, sehingga filariasis tidak menjadi masalah kesehatan di tiap kabupaten/kota. ${ }^{3}$

Berdasarkan data tahun 2008 sampai tahun 2011 tercatat 142 kasus filariasis kronis yang tersebar di 20 wilayah kerja Puskesmas. ${ }^{4}$ Tahun 2015 masih ditemukan penderita positif baru di desa sentinel dan desa spot di Kabupaten Banyuasin. Angka prevalensi mikrofilaria $<1 \%$ setelah pengobatan massal tahap III. Kepadatan mikrofilaria yang ditemukan tergolong tinggi yaitu $>50$ per mililiter darah, sehingga risiko penularannya tergolong tinggi. ${ }^{5}$

Berdasarkan hal tersebut, maka dengan menggunakan data penelitian tentang cakupan POPM, dapat menganalisis lebih lanjut untuk mengetahui faktor yang berhubungan dengan perilaku minum obat filariasis pada kegiatan pemberian obat massal filariasis di Kabupaten Banyuasin.

\section{METODE}

Penelitian ini menggunakan data dari penelitian cakupan pengobatan program pemberian obat massal pencegahan filariasis (POPM) di Kabupaten Banyuasin, Sumatera Selatan serta faktor yang mempengaruhinya. Desain penelitian menggunakan potong lintang yang dilakukan di Kabupaten Banyuasin pada Maret - November 2015.

Populasi survei cakupan POPM adalah seluruh penduduk yang tinggal di Kabupaten Banyuasin yang menjadi sasaran pengobatan massal filariasis. Sedangkan sampel adalah penduduk yang tinggal di desa terpilih yang melaksanakan pengobatan filariasis di Kabupaten Banyuasin. 
Besar sampel minimal untuk melihat faktor yang mempengaruhi cakupan pengobatan dihitung menggunakan rumus. ${ }^{6}$

$$
\mathrm{n}=\frac{\left(Z_{1-\alpha / 2}^{2} P_{1}\left(1-P_{1}\right)+P_{2}\left(1-P_{2}\right)\right)}{d^{2}}
$$

Keterangan :

$$
\begin{aligned}
& \mathrm{n} \quad=\text { Jumlah Sampel } \\
& Z_{1-\alpha}=1,96 \\
& \mathrm{P}_{1}=\text { Proporsi yang dapat obat dan } \\
& \text { minum obat }(0,79) \\
& \text { Proporsi yang dapat obat dan tidak } \\
& \mathrm{P}_{2}=\text { minum obat }(0,21) \\
& \mathrm{d}^{2}=0,05
\end{aligned}
$$

Berdasarkan perhitungan sampel minimal yang dibutuhkan 196,4 responden dengan memperhitungkan drop out $10 \%$ maka dibutuhkan sebanyak 216 responden. Pada analisis menggunakan seluruh sampel sebanyak 302 responden yang telah dikumpulkan.

Pemilihan desa dilakukan dengan cara sistematic random sampling. Kegiatan survei cakupan telah dilakukan dengan prosedur pengambilan sampel cakupan. ${ }^{7}$ Survei dilakukan mengunjungi sepuluh rumah pada setiap cluster (desa). ${ }^{8}$ Pengumpulan data dilakukan dengan wawancara menggunakan kuesioner terstruktur. Kuesioner terdiri dari beberapa pertanyaan tentang karakteristik responden, pengetahuan, persepsi kerentanan, persepsi efek samping obat, distribusi obat, jarak, kontrol petugas, penyuluhan dan sosialisasi pengobatan. Pertanyaan pengetahuan merupakan komposit dari beberapa pertanyaan mengenai filariasis. Data dianalisis menggunakan regresi logistic dengan SPSS.

\section{HASIL}

Hasil penelitian menunjukkan bahwa responden yang minum obat massal pencegahan filariasis tahap tiga ditelusuri dengan menanyakan apakah pernah minum obat filariasis pada kegiatan pengobatan massal maupun pengobatan selektif. Pembagian obat dilakukan dengan cara membagikan obat di pos-pos pembagian obat dan dibagikan oleh kader dari rumah ke rumah. Proporsi responden yang minum obat pada POPM filariasis Kabupaten Banyuasin secara rinci pada gambar 1.

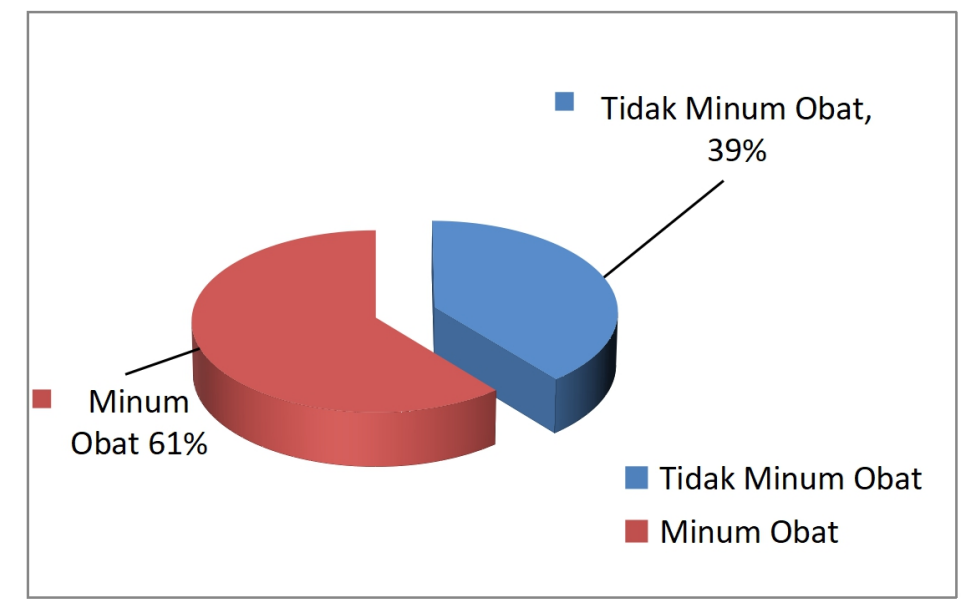

Gambar 1. Proporsi Responden yang Minum Obat pada Kegiatan POPM Filariasis Tahap 3 di Kabupaten Banyuasin

Tabel 1. dapat dilihat hubungan antara beberapa variabel dependen dengan variabel independen. Hasil analisis menunjukkan dari 12 variabel terdapat enam variabel yang mempunyai hubungan bermakna yaitu pengetahuan, persepsi kerentanan, efek samping obat, distribusi obat, kontrol petugas dan penyuluhan. 
Tabel 1. Hasil analisis bivariat antara variabel dependen dan independen

\begin{tabular}{|c|c|c|c|c|c|c|c|}
\hline \multirow[t]{2}{*}{ Variabel } & \multicolumn{2}{|c|}{ Minum Obat } & \multicolumn{2}{|c|}{$\begin{array}{c}\text { Tidak Minum } \\
\text { Obat }\end{array}$} & \multirow{2}{*}{$\begin{array}{c}\mathbf{P} \\
\text { value }\end{array}$} & \multirow[t]{2}{*}{ OR } & \multirow[t]{2}{*}{ Cl $95 \%$} \\
\hline & Jumlah & $\%$ & Jumlah & $\%$ & & & \\
\hline \multicolumn{8}{|l|}{ Umur $(n=302)$} \\
\hline Umur risiko & 114 & 61,6 & 71 & 38,4 & \multirow{2}{*}{0,809} & \multirow{2}{*}{1,078} & \multirow{2}{*}{$0,671-1,731$} \\
\hline Umur tidak risiko & 70 & 59,8 & 47 & 40,2 & & & \\
\hline \multicolumn{8}{|l|}{ Jenis Kelamin } \\
\hline Laki- Laki & 32 & 62,7 & 19 & 37,3 & \multirow{2}{*}{0,875} & \multirow{2}{*}{1,097} & \multirow{2}{*}{$0,589-2,042$} \\
\hline Perempuan & 152 & 60,6 & 99 & 39,4 & & & \\
\hline \multicolumn{8}{|l|}{ Pekerjaan } \\
\hline Tidak Bekerja & 94 & 60,6 & 61 & 39,4 & \multirow{2}{*}{1,000} & \multirow{2}{*}{0,976} & \multirow{2}{*}{$0,615-1,550$} \\
\hline Bekerja & 90 & 61,2 & 57 & 38,8 & & & \\
\hline \multicolumn{8}{|l|}{ Pendidikan } \\
\hline Tinggi & 29 & 59,2 & 20 & 40,8 & \multirow{2}{*}{0,873} & \multirow{2}{*}{0,917} & \multirow{2}{*}{$0,492-1,710$} \\
\hline Rendah & 155 & 61,3 & 98 & 38,7 & & & \\
\hline \multicolumn{8}{|l|}{ Pengetahuan } \\
\hline Baik & 94 & 71,8 & 37 & 28,2 & \multirow{2}{*}{$0,001^{*}$} & \multirow{2}{*}{2,286} & \multirow{2}{*}{$1,408-3,712$} \\
\hline Kurang & 90 & 52,6 & 81 & 47,4 & & & \\
\hline Persepsi Kerentanan & & & & & & & \\
\hline Rentan & 96 & 68,1 & 45 & 31,9 & $0.018^{*}$ & 1770 & $1105-2834$ \\
\hline Tidak rentan & 88 & 54,7 & 73 & 45,3 & 0,018 & $1,7 / 0$ & $1,105-2,834$ \\
\hline Persepsi efek samping Oba & & & & & & & \\
\hline Tidak ada efek samping & 89 & 73,6 & 32 & 26,4 & & & \\
\hline Ada efek samping & 95 & 52,5 & 86 & 47,5 & $0,000^{\star}$ & 2,518 & $1,530-4,144$ \\
\hline Distribusi Obat & & & & & & & \\
\hline Dari rumah ke rumah & 105 & 67,3 & 51 & 32,7 & $0025 *$ & 1716 & $1095-2785$ \\
\hline Datang ke pos pelayanan & 79 & 54,1 & 67 & 45,9 & $0,025^{\star}$ & $1, / 46$ & 1,095-2,/85 \\
\hline Jarak & & & & & & & \\
\hline Dekat & 166 & 60,8 & 107 & 39,2 & 1000 & 0918 & \\
\hline Jauh & 18 & 62,1 & 11 & 37,9 & 1,000 & 0,948 & 2,086 \\
\hline Kontrol Petugas & & & & & & & \\
\hline Ada & 27 & 75,0 & 9 & 25,0 & & & \\
\hline Tidak ada & 157 & 59,0 & 109 & 41,0 & $0,071^{\star}$ & 2,083 & $0,942-4,603$ \\
\hline Sosialisasi Pengobatan & & & & & & & \\
\hline Ada sosialisasi & 138 & 62,4 & 83 & 37,6 & 0.425 & 1265 & $0754-2124$ \\
\hline Tidak ada sosialisasi & 46 & 56,8 & 35 & 43,2 & 0,425 & 1,265 & $0,154-2,122$ \\
\hline Penyuluhan & & & & & & & \\
\hline Ada & 115 & 72,8 & 43 & 27,2 & & & \\
\hline Tidak Ada & 69 & 47,9 & 75 & 52,1 & $0,000^{\star}$ & 2,907 & $1,800-4,694$ \\
\hline
\end{tabular}

Seleksi awal variabel dependen yang dapat masuk sebagai kandidat model pada analisis multivariat adalah variabel yang nilai $P$ value $<0,25$. Beberapa variabel yang masuk menjadi kandidat model hanya enam variabel dependen yaitu pengetahuan, persepsi kerentanan, distribusi obat, efek samping obat, adanya kontrol petugas dan penyuluhan (Tabel 1). Hasil analisis model awal dengan memasukkan enam variabel yang memenuhi syarat, kemudian memilih variabel yang mempunyai nilai $P$ value $\leq$ 0,05 . Pengeluaran variabel dilakukan menggunakan metode enter yaitu variabel dikeluarkan secara bertahap, dimulai dengan variabel yang mempunyai $P$ value yang paling besar, sampai semua variabel mempunyai nilai $P$ value $\leq 0,05$. 
Tabel 3. Hasil analisis model akhir

\begin{tabular}{cccccc}
\hline Variabel & \multirow{2}{*}{ B } & Sig. & Exp(B) & \multicolumn{2}{c}{$95 \%$ C.I.for EXP(B) } \\
& & & & Lower & Upper \\
\hline Pengetahuan & 0,916 & 0,001 & 2,498 & 1,471 & 4,244 \\
Efek samping & 1,098 & 0,000 & 2,999 & 1,735 & 5,182 \\
Distribusi Obat & 0,948 & 0,000 & 2,582 & 1,522 & 4,378 \\
Penyuluhan & 1,092 & 0,000 & 2,982 & 1,775 & 5,010 \\
\hline
\end{tabular}

Hasil analisis didapatkan empat variabel yang dapat menjadi model untuk memprediksi minum obat filariasis, yaitu variabel pengetahuan, efek samping obat, distribusi obat dan penyuluhan. Penyuluhan merupakan variabel yang paling dominan berperan menentukan perilaku minum obat responden dengan OR 2,982. Responden yang mengalami efek samping obat 2,999 kali tidak minum obat filariasis yang dibagikan. Hasil penelitian ini menunjukkan bahwa keempat variabel menunjukkan OR yang tidak jauh berbeda.

\section{BAHASAN}

POPM filariasis pada seluruh masyarakat yang berisiko merupakan metode pencegahan yang bertujuan untuk menurunkan microfilaria rate dalam darah dengan cara membunuh seluruh cacing penyebab filariasis yang ada di seluruh populasinya. ${ }^{9}$ POPM filariasis bertujuan untuk mengeliminasi filariasis dengan cara menghilangkan kejadian penularan dari penderita ke calon penderita filariasis. Penularan akan menurun atau bahkan tidak terjadi bila jumlah mikrofilaria dalam darah manusia sangat rendah sehingga meskipun ada nyamuk sebagai vektor, tetapi gigitannya tidak mampu menularkan filariasis karena rendahnya jumlah mikrofilaria dalam darah penderita. ${ }^{10}$

Tahun 2015 Kabupaten Banyuasin telah selesai melakukan pengobatan massal filariasis putaran ketiga dan berhasil menurunkan angka prevalensi mikrofilaria $<1 \%$, namun kondisi ini masih harus diwaspadai karena hasil kegiatan survei darah jari pada penelitian ini menunjukkan kepadatan mikrofilaria pada penderita yang ditemukan tergolong tinggi yaitu > 50 per milliliter darah (Mf/ml). ${ }^{5}$ Masih tingginya kepadatan mikrofilaria dengan $>50 \mathrm{Mf} / \mathrm{ml}$ darah menunjukkan bahwa adanya potensi penularan yang cukup tinggi dan mempertahankan rantai penularan filariasis apabila tidak ada pengobatan kepada penderita atau penderita yang tidak patuh minum obat. ${ }^{11}$ Hasil penelitian di Alor menyebutkan bahwa satu responden mengalami peningkatan kepadatan mikrofilaria dari $88 \mathrm{Mf} / \mathrm{ml}$ menjadi 1356 $\mathrm{Mf} / \mathrm{ml}$ dan setelah ditelusuri responden tidak minum obat pada tahap pertama pengobatan dengan alasan efek samping dari obat yang membuat pusing ${ }^{12}$.

Persepsi responden terkait efek samping juga dapat mempengaruhi tindakan minum obat, di Kabupaten Banyuasian pada POPM filariasis tahap III sebagian besar responden merasa tidak ada efek samping saat mereka minum obat filariasis $(73,6 \%)$. Pengalaman minum obat massal filariasis pada tahap I dan II, responden merasa tidak mengalami efek samping yang ditakutkan, sehingga pada POPM filariasis tahap III ketakutan terhadap efek samping obat filariasis semakin sedikit. Hal ini sejalan dengan hasil penelitian di Kabupaten Bandung bahwa responden terpengaruh dengan melihat dampak pemberian obat sebelumnya. ${ }^{13}$

Hasil penelitian ini menunjukkan bahwa kegiatan penyuluhan merupakan faktor yang mempengaruhi perilaku minum obat filariasis pada kegiatan POPM filariasis di Kabupaten Banyuasin Provinsi Sumatera Selatan. Penyuluhan tentang kesehatan merupakan proses untuk meningkatkan kemampuan masyarakat dalam memelihara dan meningkatkan kesehatannya.

Peran petugas kesehatan yang sering memberikan penjelasan atau penyuluhan tentang cara minum obat yang benar sangat 
penting demi keberhasilan POPM. Petugas Kesehatan di Kabupaten Banyuasin telah melakukan penyuluhan melalui berbagai macam media promosi kesehatan tentang cara mengurangi efek samping dan meminimalisir penolakan masyarakat untuk minum obat filariasis pada POPM filarisis tahap I dan II. Petugas kesehatan merupakan orang yang dipercaya oleh masyarakat dalam hal ilmu kesehatan. Keberadaan petugas ini sangat diperlukan ketika ada program yang harus dijalani masyarakat. Menjelang pengobatan kurang dari satu bulan sebaiknya diadakan sosialisasi POPM oleh petugas kesehatan tentang penyakit filariasis, sehingga masyarakat dapat melaksanakan pengobatan dan menyikapi dengan benar apabila terjadi reaksi pengobatan. Kader sebagai ujung tombak di lapangan dan sebagai perpanjangan tangan petugas kesehatan mempunyai peran yang penting dalam mensosialisasikan ke masyarakat tentang pentingnya minum obat filariasis. Selain petugas kesehatan, kader juga perlu memahami tentang filariasis sehingga mereka dapat menyebarkan informasi atau pengetahuan mereka kepada masyarakat, selain itu kader sebagai anggota unit terkecil di masyarakat (keluarga) dapat memberi pengetahuan juga kepada anggota keluarganya sendiri. ${ }^{13}$ Peran dan fungsi kader kesehatan menurut Effendi dan Makhfuldli (2019) dalam lasbudi adalah meningkatkan keikutsertaan masyarakat dalam upaya pembangunan kesehatan melalui pendekatan edukatif yaitu berusaha menimbulkan kesadaran untuk dapat memecahkan masalah dengan memperhitungkan sosial budaya setempat, diharapkan masyarakat termotivasi untuk mengikuti program pemerintah dalam pemberantasan filariasis. ${ }^{14}$

Target cakupan pemberian obat pencegahan massal filariasis tergantung pada perilaku kepatuhan minum obat juga terkait erat dengan dukungan Sumber Daya Manusia (SDM) baik petugas kesehatan, kader, lintas sektor dan promosi kesehatan. Promosi POPM filariasis dengan metode penyuluhan menggunakan media yang tepat sesuai kebutuhan masyarakat dilakukan secara berkala yang disertai pendampingan oleh tenaga kesehatan dapat menjadi sarana untuk meningkatkan pengetahuan masyarakat. Kegiatan ini menjadi kesempatan yang baik untuk meyakinkan masyarakat yang masih meragukan atau takut minum obat. ${ }^{15}$

Memutus mata rantai penularan filariasis dilakukan dengan pemberian obat pencegahan massal filariasis di daerah endemis menggunakan DEC $6 \mathrm{mg} / \mathrm{kg}$ berat badan yang dikombinasikan dengan Albendazole $400 \mathrm{mg}$ sekali setahun dan dilakukan minimal lima tahun. Pelaksanaan pencegahan filariasis dilakukan dengan berbasis kabupaten, namun kelemahan program POPM filariasis ini belum dapat menjangkau seluruh penduduk di wilayah kabupaten/kota sasaran. Pola program seperti ini berpeluang terdapat risiko penularan (re-infeksi) karena belum semua penduduk terlindungi. Hal ini menunjukkan adanya indikasi beberapa masyarakat wilayah sasaran POPM filariasis di Kabupaten Banyuasin belum semuanya terjangkau pengobatan massal filariasis atau belum terdistribusinya secara merata obat massal filariasis pada penduduk karena pada pengobatan massal filariasis tahap III hanya sebesar 61 persen masyarakat di wilayah sasaran minum obat massal filariasis. Kondisi geografis Kabupaten Banyuasin sebagian besar perairan. Wilayah seperti ini menjadi kendala untuk menjangkau seluruh masyarakat di wilayah Kabupaten Banyuasin. Moda transportasi yang digunakan untuk menjangkau desa-desa lebih banyak menggunakan transportasi air seperti kapal, getek dan perahu. Ada sebagian kecil desa untuk menjangkaunya tergantung kondisi pasang surut air sungai. Kondisi geografis pada wilayah endemis khususnya desa-desa terpencil yang sulit dijangkau menjadi salah satu penyebab tidak meratanya pembagian obat massal filariasis. ${ }^{16}$ Di Kabupaten Manggarai Timur juga menggambarkan permasalahan yang sama dimana $83 \%$ permasalahan pelaksanaan POPM filariasis di Kabupaten tersebut salah satunya belum merata pendistribusian obat anti filariasis. ${ }^{17}$

Pengetahuan merupakan faktor penting untuk terbentuknya tindakan seseorang (oven behavior) ${ }^{18}$. Hasil penelitian ini menunjukkan bahwa di 
Kabupaten Banyuasin pengetahuan merupakan faktor yang mempengaruhi perilaku minum obat pada kegiatan POPM, dengan demikian semakin baiknya pengetahuan masyarakat di wilayah sasaran POPM filariasis dapat mempengaruhi perilakunya untuk minum obat filariasis. Adanya hubungan yang bermakna antara pengetahuan responden dengan tindakan minum obat massal filariasis tahap III di Kabupaten Banyuasin, hal ini sejalan dengan hasil penelitian lainnya yang menunjukkan pengetahuan responden tentang POPM mempunyai hubungan yang bermakna terhadap tindakan minum obat filariasis ${ }^{19,20}$.

Adanya peningkatan pengetahuan tentang filariasis berdampak pada persepsi responden terkait dengan kerentanan atau bahaya dari penyakit ini. Persepsi kerentanan memotivasi seseorang untuk melakukan tindakan untuk mencegah suatu penyakit dalam hal ini adalah filariasis. ${ }^{16}$ Sebagian besar responden merasa penyakit filariasis merupakan penyakit yang serius dan berbahaya. Mereka berpeluang besar tertular filariasis jika tidak rutin minum obat massal filariasis.

Pengawasan minum obat dalam pengobatan massal sangat penting agar target cakupan minum obat meningkat dan target $\mathrm{mf}$ rate $<1 \%$ tercapai. ${ }^{21}$ Pengawasan atau monitoring minum obat pada kegiatan POPM filarisis ini dilakukan oleh kader, baik dilakukan dengan mendatangi ke rumah-rumah atau di pos pengobatan. $\mathrm{Di}$ dalam pengawasan/monitoring ini masyarakat diminta untuk minum obat POPM filariasis di depan kader. Hasil penelitian di India menggambarkan bahwa penyebab rendahnya cakupan minum obat selain adanya efek samping juga disebabkan adanya pemberian obat yang tidak diawasi ${ }^{22}$.

Pengobatan massal bukan merupakan satu-satunya upaya untuk pemberantasan filariasis karena filariasis merupakan penyakit zoonosis yang ditularkan melalui gigitan nyamuk. Selain pengobatan massal juga dilakukan usahausaha lainnya yang dapat memutuskan rantai penularan filarisis, salah satunya dengan menghindari/mengurangi kontak dengan nyamuk sebagai vektor filariasis. Upaya yang dapat dilakukan dengan memperbaiki perilaku berisiko menjadi tidak berisiko, seperti memakai kelambu dan memakai obat anti nyamuk. Dalam penelitian ini responden sudah melakukan pencegahan filariasis dengan menggunakan kelambu saat tidur, baik siang hari maupun malam hari. Selain menggunakan kelambu mereka juga memakai obat nyamuk bakar maupun oles.

\section{KESIMPULAN}

Terdapat empat faktor yang berhubungan dengan cakupan minum obat yaitu pengetahuan tentang filariasis, persepsi terhadap efek samping obat, cara distribusi obat dan kegiatan penyuluhan. Faktor yang paling berhubungan adalah penyuluhan setelah dikontrol oleh variabel pengetahuan, distribusi obat dan efek samping.

\section{SARAN}

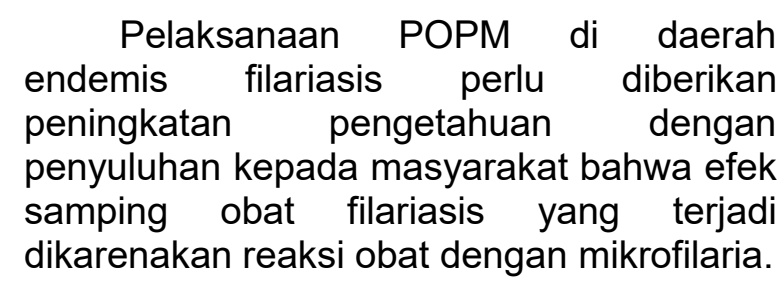

\section{KONTRIBUSI PENULIS}

$\mathrm{RT}$, RO dan IM sebagai kontributor utama dalam penulisan artikel ini yang bertanggung jawab pada konsep, metode, analisis dan pembahasan.

\section{UCAPAN TERIMA KASIH}

Ucapan terima kasih penulis sampaikan kepada Kepala Balai Penelitian Pengembangan Kesehatan Baturaja, Kepala Dinas Kesehatan Provinsi Sumatera Selatan dan Kepala Dinas Kesehatan Kabupaten Banyuasin, beserta semua staf yang telah membantu selama pelaksanaan penelitian, serta semua pihak yang tidak dapat disebutkan satu persatu.

\section{DAFTAR PUSTAKA}

1. Kementerian Kesehatan RI. Peraturan Menteri Kesehatan Repubik Indonesia 
Nomor 94 Tahun 2014, Tentang Penanggulangan Filariasis.; 2014:1118.

2. Kementerian Kesehatan RI. Rencana Nasional Program Eliminasi Filariasis $2010 \quad$ - 2014.; 2010. http://pppl.depkes.go.id/_asset/_downlo ad/NATIONAL_PLAN_FILARIAS̄IS_20 10-IND_2010-14.pdf.

3. Santoso, Taviv $Y$, Mayasari R. Pengaruh Promosi Kesehatan terhadap Pengetahuan, Sikap dan Perilaku Masyarakat Tentang Filariasis. Bul Penelit Sist Kesehat. 2014;17(2):167176.

4. Banyuasin DK. Laporan Tahunan Eliminasi Penyakit Kaki Gajah Kabupaten Banyuasin Propinsi Sumatera Selatan.

5. Oktarina R, Santoso S, Taviv $\mathrm{Y}$. Gambaran Angka Prevalensi Mikrofilaria di Kabupaten Banyuasin Pasca Pengobatan Massal Tahap III Microfilaria Rate in Banyuasin District Post Mass Drug Administration Round III. BALABA. 2017:11-20.

6. Lemeshow. Besar Sampel Dalam Penelitian Kesehatan. Jogyakarta: Gajah Mada University Press; 1997.

7. Depkes RI. Pedoman Pengobatan Massal Penyakit Kaki Gajah. In: Jakarta: Dirjen PP\&PL; 2008.

8. Lemeshhow. Besar Sampel Dalam Penelitian Kesehatan. (Press GMU, ed.). Yogyakarta; 1997.

9. Syaiful Bahtiar, Joni Herman AR. Perilaku Minum Obat Anti Filariasis di Kelurahan Rawa Mambok. Wawasan Kesehat. 2017;4(1):1-6.

10. Ambarwati, Dwi Pratiwi. Evaluasi Program Eliminasi Filariasis Melalui POPM Filariasis Dengan Minum Obat Di Tempat. J Profesi Keperawatan. 2018;5(2):1-15.

11. Suryaningtyas $\mathrm{NH}$, Arisanti $M$, Satriani AV, Inzana N, Santoso S, Suhardi S. Kondisi Masyarakat pada Masa Surveilans Pasca-Transmission Assessment Survey (TAS)-2 Menuju Eliminasi Filariasis di Kabupaten
Bangka Barat, Bangka Belitung. Bul Penelit Kesehat. 2018;46(1):35-44. doi:10.22435/bpk.v46i1.55

12. Supali $T$, Djuardi $Y$, Bradley $M$, Noordin $R$, Rückert $P$ FP. Impact of Six Roundsof Mass Drug Administration on Brugian Filariasis and Soil-Transmitted Helminth Infections in Eastern Indonesia. PLoS Negl Trop Dis. 2013;7(12):1-9.

13. Ipa M, Astuti EP, Hakim L, Fuadzy H. Analisis Cakupan Obat Massal Pencegahan Filariasis $\mathrm{Di}$ Kabupaten Bandung Dengan Pendekatan Model Sistem Dinamik. BALABA. 2016;12(1):31-38.

doi:10.22435/blb.v12i1.4470.31-38

14. Ambarita LP, Taviv $Y$, Sitorus $H$, Pahlevi RI, Kasnodiharjo. Perilaku Masyarakat Terkait Penyakit Kaki Gajah di Kecamatan Pemayung Kabupaten Batanghari, Jambi. Media Litbangkes. 2014;24(4):191-198. doi:10.22435/mpk.v24i4.3673.191-198

15. Sitorus $H$, Ambarita LP, Arisanti $M$, Manalu HS. Pengetahuan Tokoh Masyarakat dan Kader Kesehatan Tentang Program Eliminasi Filariasis Limfatik di Kecamatan Pemayung Kabupaten Batanghari Provinsi Jambi. ASPIRATOR. 2017;8(2):93-100. doi:10.22435/aspirator.v8i2.4980.93100

16. Hayden J. Introduction to Health Behavior Theory. Jones \& Bartlett Learning; 2014.

17. Onggang FS. Evaluasi Implementasi "POMP" Filariasis Dan Faktor Yang Berhubungan Dengan Permasalahannya Di Kabupaten Manggarai Timur Tahun 2017. J Info Kesehat. 2017;15(1):45-69.

18. Fitriyanti $A$, Natalia $D$, Rahmayanti $S$, et al. Gambaran pengetahuan, Sikap dan Perilaku Penduduk terhadap Filariasis di Desa Bata Lura Kecamatan tanah Pinoh Kabupaten Melawi Tahun 2015 Latar Belakang Data kasus filariasis di Kabupaten Melawi pada tahun adalah WHO tahun 2000 . Program eliminasi filari. J Cerebellum. 2015;3(3):861-873. 
19. Alamsyah A. Faktor-Faktor yang Berhubungan Dengan Cakupan Menelan Obat Massal Pencegah Filariasis. J Endur. 2016;1(1):17-22. doi:10.22216/je.v1i1.586

20. Nurlaila, Praba Ginandjar M. Faktorfaktor yang berhubungan dengan Kepatuhan Pengobatan Masal di Kelurahan Non Endemis Filariasis Kota Pekalongan. J Kesehat Masy. 2017;5 Nomor $4: 455-466$. https://ejournal3.undip.ac.id/index.php/j km/article/view/18662. Accessed March
21, 2018.

21. Wahyudi BF, Pramestuti N. Kondisi Filariasis Pasca Pengobatan Massal di Kelurahan Pabean Kecamatan Pekalongan Utara Kota Pekalongan. BALABA. 2017;12(1):55-60. doi:10.22435/blb.v12i1.4635.55-60

22. Marathe N CC. Mass Drug Administration Coverage Evaluation For Elimination Of Lymphatic Filariasis In Chhatarpur District of Madhya Pradesh. Int J Med Sci Public Heal. 2015;4(7):927-32. 